\title{
Temporal assessment of heavy metal concentration and surface water quality representing the public health evaluation from the Meghna River estuary, Bangladesh
}

\author{
M. Safiur Rahman ${ }^{1}$ - A. S. Shafiuddin Ahmed ${ }^{2}$. Md. Moshiur Rahman² - S. M. Omar Faruque Babu² . \\ Sharmin Sultana ${ }^{3} \cdot$ Shafiqul Islam Sarker ${ }^{4} \cdot$ Rabiul Awual $^{5} \cdot$ Mohammad Majibur Rahman $^{6} \cdot$ Mostafizur Rahman $^{6}$ iD
}

Received: 27 March 2020 / Accepted: 15 June 2021 / Published online: 23 June 2021

(c) The Author(s) 2021

\begin{abstract}
The Meghna River, the largest and the widest river in Bangladesh, is important for navigation, irrigation, fish spawning and shelter, industrial usages, and drinking water sources for millions of people living in nearby areas. The present study illustrated the seasonal variation of some physicochemical parameters and the four heavy metals $(\mathrm{Cr}, \mathrm{As}, \mathrm{Cd}, \mathrm{and} \mathrm{Pb})$ distribution in the surface water of Meghna River estuary. It also evaluated the human health risk for adult and children due to directly contact with the surface water through ingestion and dermal pathways. The ranges of metal concentration in the study area were found in the descending order as: $\mathrm{Cr}(0.036-0.054$; mean $0.045 \pm 0.005)>\mathrm{As}(0.012-0.036$; mean $0.024 \pm 0.007)>\mathrm{Cd}$ $(0.009-0.050$; mean $0.018 \pm 0.012)>\mathrm{Pb}(0.007-0.014$; mean 0.009 \pm 0.007$)$. In most cases, the concentrations of As, $\mathrm{Cr}$, $\mathrm{Pb}$, and $\mathrm{Cd}$ surpassed the guideline limits of human consumption. However, the one-way ANOVA study revealed that the average concentrations of the selected metals in the ten sampling sites were not significantly different at a $95 \%$ confidence level. Therefore, it is assumed that the metal contamination in the study area might have been caused due to the anthropogenic sources along with the natural phenomenon. The distribution of the metal contents and the physicochemical parameters in the surface water greatly were significantly different concerning both winter and summer seasons at a $95 \%$ confidence level. The evaluated hazard quotient (HQ) and the hazard index (HI) for the investigated metal compounds were in the acceptable limit $(<1)$. In addition, the attribution of metal contents did not overweigh the carcinogenic risk (CR) range $\left(10^{-6}\right.$ to $\left.10^{-4}\right)$, and the adults are more susceptible than the children. Although the risk is within the acceptable level, but adequate monitoring aspects should be implemented to control surface water pollution especially for the metal discharge to the river estuary.
\end{abstract}

Keywords Heavy metal $\cdot$ Physicochemical parameter $\cdot$ Seasonal variation $\cdot$ Surface water $\cdot$ Health risk $\cdot$ Meghna river estuary

Mostafizur Rahman

rahmanmm@juniv.edu

1 Atmospheric and Environmental Chemistry Laboratory, Chemistry Division, Atomic Energy Centre Dhaka (AECD), GPO Box 164, Dhaka 1000, Bangladesh

2 Department of Fisheries and Marine Science, Noakhali Science and Technology University, Sonapur, Noakhali 3814, Bangladesh

3 Department of Chemistry, National University, Gazipur 1704, Bangladesh
4 Forensic Science Laboratory, Rapid Action Battalions Headquarters, Dhaka 1229, Bangladesh

5 Actinide Coordination Chemistry Group, Quantum Beam Science Directorate, Japan Atomic Energy Agency (SPring-8), Hyogo 679-5148, Japan

6 Department of Environmental Sciences, Jahangirnagar University, Dhaka 1342, Bangladesh 


\section{Introduction}

A sustainable water quality is one of the crucial environmental requirements for any aquatic life (Zhai et al. 2014). Scholars accorded that quality of the surface water body is also necessary for socioeconomic development, environmental and ecological balance (Islam et al., 2020). Accumulation of heavy metals in an aquatic environment (both fresh and marine) has become a major concern, especially for developing countries (Ahmed et al. 2015a, b). Anthropogenic activities, like unplanned industrialization, excessive use of chemicals, are main causes for the presence of high levels of metals in the aquatic ecosystems (Ahmed et al. 2019a). Excess level of the metal attribution to the aquatic environment can enhance the acute toxicity that can pose significantly adverse consequences on the sediment, water quality, and the inhibited aquatic organisms (Ahmed et al. 2019a; Hossain et al. 2019). For instance, aquatic organisms like gastropods can experience many physiological complications, like the development of 'imposex' nature-a phenomenon in which male sex characteristic develops on female responding to the metal effluents and other refractory organic accumulated compounds like tributyltin (Guo et al. 2010; Alzieu 2000).

Likewise, human body is to be exposed to the toxic heavy metals through different pathways like ingestion, dermal contact and inhalation (Ahmed et al. 2021; Hossain et al. 2021). Thereby, various long-lasting chronic impacts like liver damage, respiratory failure, blood circulation, skin cancer can be occurred that can lead to even death (Wei et al. 2014). In the aquatic ecosystem, under certain physiological and environmental conditions, heavy metals pose their impact in photosynthesis and thereby reduce the growth and diversity of the phytoplankton community (Tchounwou et al. 2012). Moreover, the breakdown of primary producer growth in particular ecosystem ultimately disrupts the whole trophic transfer systems and the food web making the living beings in a state of total jeopardize (Winder and Schindler 2004).

Estuary environment in Bangladesh, a natural blessing, is highly susceptible to anthropogenic impacts (MEA 2005) and prone to soil erosion, natural disasters, and other environmental pollution. The estuaries are the most perplexing, highly prolific, and dynamic systems in nature (Hossain et al. 2019). The discharged untreated municipal wastes, unprocessed sewages from various industries and agrochemicals go mixed up with the open water bodies and thus become very hazardous and toxic. Being persistent in nature, the metal effluents are potentially bioavailable and toxic to the aquatic biota in the estuary environment (de Souza et al. 2016). The aggregation of refractory organic pollutants and disposed metal contents greatly decline the surface water quality making unfit for drinking purpose (Islam et al. 2015a, b). To assess the adverse impact of metals in the aquatic environment and human health, it is necessary to investigate the concentration of metals in the surface water (Saleem et al. 2015). Hence, the exploration and quantification of heavy metal loads in the water body show an effective way to assess the anthropogenic influence and associated health hazards posed by the extensive releases of the pollutants to the estuary ecosystems (Zheng et al. 2008).

The Meghna River is one of the largest and the widest river systems in Bangladesh (Banglapedia 2015b). It is important for navigation, irrigation, fish spawning and shelter, industrial usages (fertilizers and cement) and drinking water sources for nearby thousands of people. The river is continuously receiving comprehensive havoc of various metal effluents from mills and industries, such as spinning, dying, cotton, textile, and steel, along with oil refineries which are making the river polluted gradually (Hassan et al. 2015). Yet, no systematic research approach concerning the heavy metal pollution in the surface water of the Meghna River estuary has been conducted. Bhuyan et al. (2017) conducted an investigation regarding metal concentration, but the study was confined in only temporal distribution of some metal components. Moreover, to date, there is no adequate investigation concerning human health risk due to drink the contaminated river water by various metal contents. Therefore, it is very essential to measure the concentrations of metal contents from the surface water of the Meghna River estuary to find out the associated ecological and human health implications. The objectives of the study are: (i) to evaluate the water quality parameters of the Meghna River estuary; (ii) to determine the levels of heavy metals in water; (iii) to assess the status of heavy metal contamination, and (iv) to evaluate the implication of their risk to human health.

\section{Materials and methods}

\section{Description of the study area}

The Meghna River is situated in the hilly region, the eastern part of India, and the upper catchment of the Bay of Bengal. The river enters into Bangladesh through the Kishoreganj District. A large number of settlements, towns, ports, and various businesses center have been launched on the both sides of the river banks. Narsingdi, Chandpur, Barisal, and Bhola are the considerable regional towns that are situated on the river banks. Sixteen kilometers from Shatnol, the consolidated progression of the Ganges and BrahmaputraJamuna, known as the padma, meets the Meghna at $11 \mathrm{~km}$ wide conversion in the monsoon season close to Chandpur. Starting from here to southwards, the Meghna is set apart 
as the Lower Meghna, getting perhaps the broadest waterway and largest estuaries on the planet (Banglapedia 2015a). The adjoining Bay of Bengal is located in the south fringe of the river. The physical condition of the estuary is difficult to describe due to the complexity of various driving force such as tides, bathymetry, hydrology, and meteorological conditions (Jakobsen et al. 2002). Tides from the Bay of Bengal is considered one of the crucial flow features of the estuary contributing particularly residual circulation (Azam 2000). The volume of the estuarine discharge is not known; however, at Chandpur, the mean discharge volume is around 2.5 million cusecs from June to October and the average in this time of the year is around 4 million cusecs (Banglapedia 2015a). Although the river estuary is several kilometers wide, the water flow in winter season is almost one eight of it due to the river's sluggishness. Nevertheless, the maximum water flow in the rainy season is greater than 5 million cusecs (Banglapedia 2015a). The river estuary is used to move in various directions by clustering a wood or steel made engine boats. At present, the study area was considered as one of the important water reservoirs near the countryside people across the river. The region is a vibrant fishing zone and the people living near the bank of the river use the reservoir as one of the potential sources of drinking and irrigation purposes. The bed elevation of the study area displays an offensive bed elevation pattern for the effective tidal stream complications. Along with these, the estuary serves as crucial habitats to well-diversified aquatic organisms, navigation routes for many tankers and ships due to has a decent geographical position.

\section{Sample collection and analysis process and accuracy}

Ten water samples with same volume of three replicates samples have been collected from the ten segmented sites of the Meghna river estuary $\left(22.457652^{\circ}\right.$ latitude, $91.103442^{\circ}$ longitude to $22.708019^{\circ}$ latitude, $90.75659^{\circ}$ longitude) in two different seasons, winter (January-March, 2018) and summer (June-August 2018) (Fig. 1). In winter season (December-March), the river is relatively dry due to little precipitation than in summer or rainy reason (April-October) when it is regarded one of the flooded river basin in

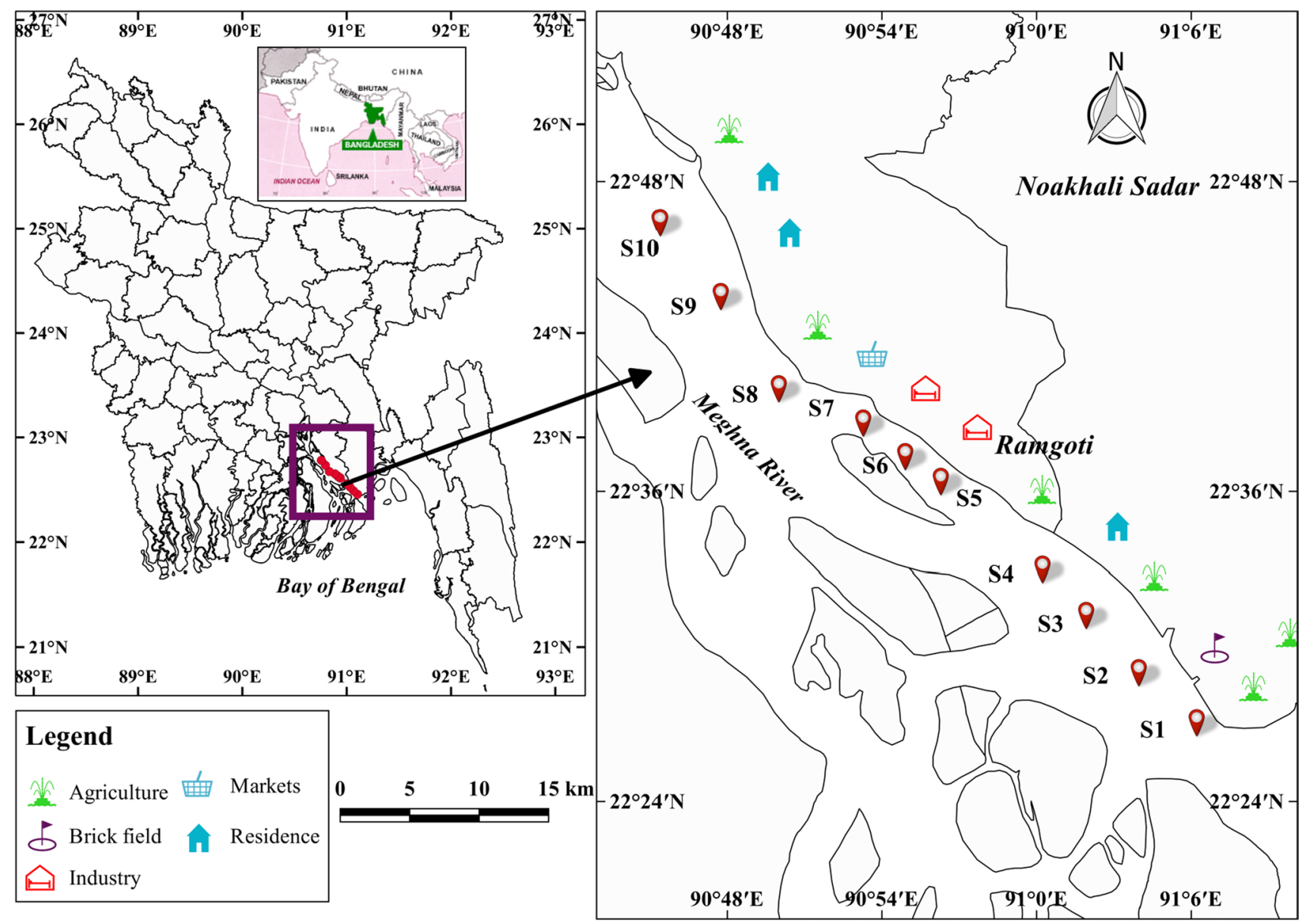

Fig. 1 Sampling sites along the Meghna River estuary, near the Bay of Bengal in Noakhali District, Bangladesh 
Bangladesh. We followed 'clean hands/dirty hands' strategies to avoid contamination while sampling (Liu et al. 2019). The collected samples were acidified with $12.5 \mathrm{~mL}$ (2.0 mL/L) of concentrated $\mathrm{HNO}_{3}(68 \%$, Merck, Germany). Before that, the three respective samples for each sampling season (winter and summer) were combined to have a respective composite sample for two different season and the composite samples were processed for three times independently. The acidified samples were refrigerated at $4{ }^{\circ} \mathrm{C}$ in the laboratory. The metal concentration was detected using an inductively coupled plasma mass spectrometry (ICP-MS, ELAN9000, PerkinElmer, Germany) at the Chemistry Laboratory of Rapid Action Battalion (RAB), Dhaka, Bangladesh, Headquarters. A standard solution for multi-elements (Merck, Germany) was used to determine the metal concentration in the water samples. Analytical blanks associated with the standard reference material were run in the similar way as the samples. Moreover, certified reference material (CRM 320) supplied by Merck KGaA from Germany was utilized to qualify the accuracy, precision, and the validity of data of analytical process. Results from the analytical methods concerning the metal contents revealed an affirmative agreement between the reference and analytical values of the reference materials. The recovery percentage was detected between 95 and $105 \%$ for the all the metal compounds. There was no additional contamination during analysis procedures, and the relative standard deviator (RSD) of the replicate samples was less than $10 \%$.

\section{Statistical analysis}

The mathematical calculations were performed using the Microsoft Excel 16 (Microsoft Corporation, USA). To identify the degree of substantial correlations among the selected variables, Spearman correlation analysis was adopted. Both the correlation and the principal component analysis (PCA) were executed using Origin 9.5 (OriginLab Corporation, USA). The principal component analysis (PCA) is a multivariate statistical analysis method that is frequently used to simplify large, complex data sets and identify correlated variables (i.e., possible common sources) without damaging the main components. The purpose of the PCA is to reduce the number of variables that explain the total variance within the data. Moreover, the significant difference $(p \leq 0.05)$ among the metals and the physicochemical features in water samples was tested individually for each seasons by one-way ANOVA using SPSS (IBM, USA). The normality test among the elements was conducted by the Kolmogorov-Smirnov and the Shapiro-Wilk, whereas the homogeneity test of the data was checked by means of the Levene's test (Ahmed et al. 2019a, b). The Kruskal-Wallis test was employed for the non-normally and non-homogeneous variables (Sun et al. 2015). On the other hand, the two-way hierarchical cluster (heat map) analysis was tailored by the use of Origin 9.5 (OriginLab Corporation, USA).

\section{Determination of metal pollution}

To determine the pollution load in the study area, pollution load index (PI) was employed for different pollutants. The index represents a cumulative effect of elements in water sample (Bhattacharya et al. 2015). The PI is estimated by calculating the sum of the ratio of metal concentration against the recommended standard guideline (Liu et al. 2011) as per Eq. [Eq. (1)]:

$\mathrm{PI}=\sum_{i=1}^{n} \frac{\mathrm{Cn}}{\mathrm{St}}$

where $\mathrm{Cn}$ is the concentration level of a particular metal and $\mathrm{St}$ is the standard guideline limit in Bangladesh proposed by the Department of Environment (DoE) as As: $0.05 \mathrm{mg} / \mathrm{L}$, Cd: $0.005 \mathrm{mg} / \mathrm{L}, \mathrm{Cr}: 0.05 \mathrm{mg} / \mathrm{L}$, and $\mathrm{Pb}: 0.05 \mathrm{mg} / \mathrm{L}$ (DoE 1997). The estimated PI values have been represented on a six-category drinking water quality ranking based on the degree of anthropogenic influences of the selected elements studied (Mitra et al. 2018): PI $<0.3$ denotes class 1 (very pure), $0.3<\mathrm{PI}<1$ denotes class 2 (pure), $1<\mathrm{PI}<2$ denotes class 3 (slightly affected), $2<\mathrm{PI}<4$ denotes class 4 (moderately affected), $4<\mathrm{PI}<6$ denotes class 5 (highly affected), and PI $>6$ denotes class 6 (tremendously affected).

\section{Risk assessment}

\section{Estimated daily intake}

The risk assessment of the selected elements was carried out to identify the exposure level and the tendency of the elements accumulates in the human body (Mitra et al. 2018). In this case, two distinct exposure pathways were considered: ingestion (through an intake of water) and dermal (through skin contact) (Yuan et al. 2014). The US Environmental Protection Agency (US EPA) has established a formula to determine the human health hazard index for the targeted exposure pathways - ingestion and dermal absorption (Liu et al. 2013; USEPA 1989).

$\mathrm{EDI}($ ingestion $)=\frac{\mathrm{CN} \times \mathrm{EF} \times \mathrm{ED} \times \mathrm{IR}}{\mathrm{BWt} \times \mathrm{AT}}$

$\mathrm{EDI}($ dermal $)=\frac{\mathrm{CN} \times \mathrm{SA} \times \mathrm{KC} \times \mathrm{EF} \times \mathrm{ED} \times \mathrm{ET} \times \mathrm{ABS}}{\mathrm{BWt} \times \mathrm{AT} \times 10^{6}}$

where $\mathrm{CN}$ is the metal concentration $(\mathrm{mg} / \mathrm{kg})$; $\mathrm{EF}$ is the exposure frequency: $365 \mathrm{~d} / \mathrm{y}$ (USEPA 2011a,b); ED is the exposure duration: 70 (adult) and 6 (child) (USEPA 2002); 
IR is the ingestion rate: $30 \mathrm{~L} / \mathrm{d}$; (USEPA 2002); BWt is the body weight of the individuals: 70 for adults and 15 for children (USEPA 1991); AT is the average time for the element: $365 \times E D d$ (non-carcinogenic elements) and $365 \times 70$ (carcinogenic elements) (USEPA 2011a,b); SA is the skin surface area for the exposure contact: $5700 \mathrm{~cm}^{2} / \mathrm{d}$ (adult), $2800 \mathrm{~cm}^{2} / \mathrm{d}$ (child) (USEPA 2011a,b); KC is the factor of permeability for dermal contact: $0.001 \mathrm{~cm} / \mathrm{h}$; ET is the exposure time: $24 \mathrm{~g} / \mathrm{d}$; ABS is the fraction of dermal absorption: 0.03 (for As) and 0001 (other metals) (USEPA 2011a,b); $10^{6}$ is the conversion factor (USEPA 2002).

\section{Non-carcinogenic risk assessment}

The degree of risk exposures of the metal contamination of the elements to the human health was estimated by calculating the hazard quotient (HQ) and hazard index (HI) equations (Saha et al., 2017):

$\mathrm{HQ}_{i p}=\frac{\mathrm{EDI}_{i p}}{\mathrm{RfD}_{i p}}$

$\mathrm{HI}=\sum_{i=1}^{n} \mathrm{HQ}_{i p}$

where EDI is the estimated daily intake of the element from water $(\mathrm{mg} / \mathrm{kg} / \mathrm{d})$ for the ingestion and dermal contact; $R_{\mathrm{f}} D$ is the reference dose of each element for the selected pathways of adult and children, provided by the USEPA as As: 0.0003, Cd: $0.001, \mathrm{Cr}: 0.003$, and $\mathrm{Pb}: 0.0035$ for ingestion, and As: $0.012 \times 10^{-3}$, Cr: $0.015 \times 10^{-3}$ and $\mathrm{Pb}: 0.42 \times 10^{-3}$ for dermal contact (USEPA 2010a, b). $R_{\mathrm{f}} D$ of Cd was considered for only oral value. The observed value which is higher than 1 reveals that the receptors will experience the non-carcinogenic health effect (Hossain et al. 2018). Moreover, $\mathrm{HI} \geq 1$ determines the long-term hazardous health effect that should be inspected properly (Singh and Kumar 2017; Zhao et al. 2018).

\section{Carcinogenic risk assessment}

A carcinogenic risk is to be assessed to determine the development of cancer of an individual for a particular carcinogen (Ahmed et al. 2021). The results deliberate the risk of exposure due to the available specific slope factor (CSF) of carcinogens (USEPA 2014).

$$
\begin{aligned}
& \mathrm{CR}_{i}=\mathrm{CSF}_{i} \times \mathrm{EDI}_{i} \\
& \mathrm{CR}=\sum_{i=1}^{n} \mathrm{CR}_{i}
\end{aligned}
$$

where $\mathrm{CR}_{i}$ is the carcinogenic risk for each element for the specific pathways; $\mathrm{CSF}_{i}$ is the slope factor for the particular metal that defines the probability of progressing cancer (Adamu et al. 2015). CSF can vary for different pathways (Kamunda et al. 2016) as As: $1.5 \mathrm{mg} / \mathrm{kg} /$ day, $\mathrm{Pb}: 0.0085 \mathrm{mg} /$ $\mathrm{kg} / \mathrm{day}$, and Cd: $6.3 \mathrm{mg} / \mathrm{kg} / \mathrm{day}$ for ingestion, and As: $1.5 \mathrm{mg} /$ $\mathrm{kg} / \mathrm{day}, \mathrm{Pb}: 0.0085 \mathrm{mg} / \mathrm{kg} / \mathrm{day}$, and $\mathrm{Cd}: 15 \mathrm{mg} / \mathrm{kg} /$ day for dermal contact (Cancer 2011; USEPA 2011a,b). The acceptable limit for lifetime exposure of CR varies from $10^{-6}$ to $10^{-4}$ (Yin et al. 2015; USEPA 2000). The CR value greater than $10^{-4}$ indicates the probability of potential carcinogenic risk (Hu et al. 2017; USEPA 2010a, b).

\section{Results and discussion}

\section{Physicochemical properties}

The physicochemical parameters are considered vital features for their significant consequence on the water quality standards. Furthermore, aquatic lives depend on the quality of water, and also suffer in the long run due to the decrepitude of water quality. The seasonal variation of different physicochemical properties (temperature, $\mathrm{pH}, \mathrm{DO}$, hardness, ammonia, and salinity) of the Meghna River estuary water samples is presented in Table 1. We observed that there was no significant difference for the physicochemical parameters in water sample collected from the different sampling points of the river at a $95 \%$ confidence level $\left(F_{\text {stat }}=0.949<F_{\text {crit }}=1.697 ; p=0.535\right)$.

Temperature is one of the remarkable external factors that may influence the survival of aquatic life (O'Connor et al. 2007). A significant temperature fluctuation $(p<0.05)$ was observed between the two seasons of study: The summer is warmer $\left(28.9-33.7^{\circ} \mathrm{C}\right)$ than the winter $\left(20.2-23.5^{\circ} \mathrm{C}\right)$. The mean water temperature $\left(26.5^{\circ} \mathrm{C}\right)$ stayed within the maximum permissible limits of WHO $\left(25\right.$ and $\left.30^{\circ} \mathrm{C}\right)$. The $\mathrm{pH}$ was higher in winter than the summer, and the average $\mathrm{pH}$ was observed at 7.92 and 8.26 during the summer and the winter seasons, respectively (Table 1 ). The maximum permissible levels of $\mathrm{pH}$, set by the EQS for Bangladesh water quality standards (EQS 1991), in industrial discharged water, water for fish culture, and drinking purposes are 6.0-9.5, 6.5-8.5, and 6.5-8.5, respectively. From our present study, it is clear that the average $\mathrm{pH}$ of the Meghna River estuary water remained below the safe limit concerning the EQS standard. The salinity is a measure of salt content in water samples; in terms of salinity, water can be divided into three basic classes: freshwater, brackish water, and marine water. The salinity range of the study area generally belongs to the brackish water range, distinctive from the marine $(>13$ ppt) or freshwaters ( $<0.05 \mathrm{ppt})$. In the Meghna River estuary, the mean salinities were observed as 8.98 and $9.34 \mathrm{ppt}$

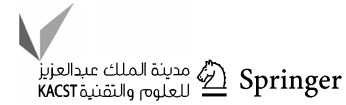




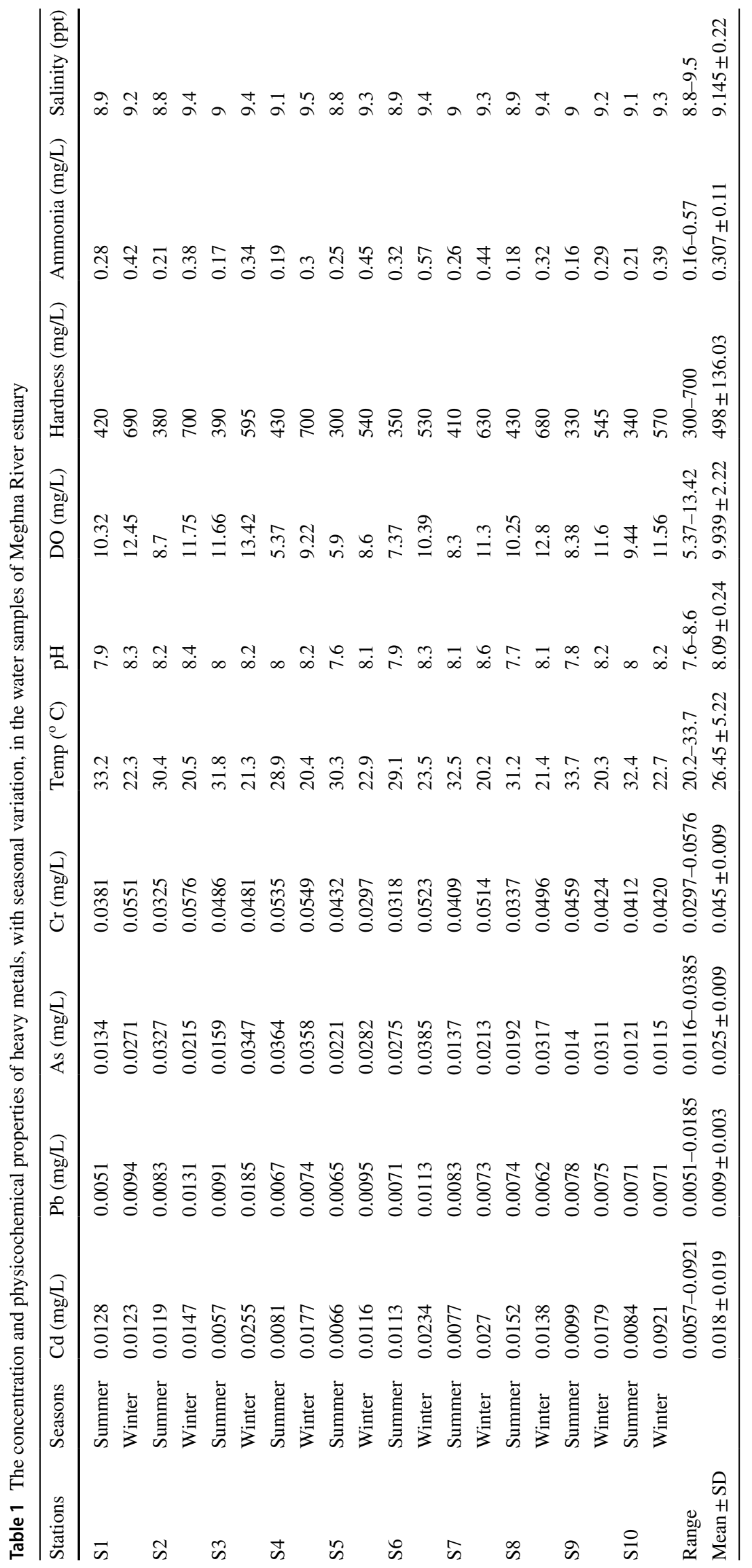


in the summer and winter seasons, respectively. The highest value of water hardness $(700 \mathrm{mg} / \mathrm{L})$ was detected in the sample site, S4 during the winter study. This was rather a high value, which was attributed to an elevated level of water salinity. The lowest water hardness $(300 \mathrm{mg} / \mathrm{L})$ was measured during the summer season in the sample site, S5 (Table 1) which was also attributed to a low salinity load. The dissolved oxygen (DO) is an indication of available gaseous oxygen present in the water body, which is important for the very survival of aquatic life. The DO level of water gives a quick assessment of the purity of water. However, the DO level of water decreases with increasing temperature (Barnett et al. 2004). In our present study, the highest level $(8.6-13.42 \mathrm{mg} / \mathrm{L})$ of DO was recorded during the winter observation, and the summer study represented the lowest value $(5.37-11.66 \mathrm{mg} / \mathrm{L})$. The relatively low DO level in the summer season could be attributed to the low precipitation rate and an increase in water temperature. Also, slow oxygen production by aquatic organisms, a high rate of microbial activity, and a speedy decomposition of organic matter may result in a smaller value of DO in the summer season. According to EQS (1991) prescription, the minimum admissible level of DO for drinking water, fisheries culture water, industrial zone water, and water used for irrigation purposes are 6.0, 4.6, 5.0, and $5.0 \mathrm{mg} / \mathrm{L}$, respectively. The DO $(5.37-13.42 \mathrm{mg} / \mathrm{L})$ levels at all the study locations in the Meghna River estuary were observed comparatively higher than that of good quality water. Apart from elemental species, the presence of ammonia in the aquatic body draws attention for several reasons. Ammonia, the primary form of gaseous ammonia $\left(\mathrm{NH}_{3}\right)$, is basically toxic, and at a concentration of $0.53-22.8 \mathrm{mg} / \mathrm{L}$, it exhibits toxicity to freshwater organisms. However, plants that grow in water are more tolerant of ammonia than animals, but invertebrates are more tolerant than fish. The hatching and the growth rates of fishes may be affected by the toxicity of ammonia. Aquatic organisms will face severe toxic effects of ammonia $\left(\mathrm{NH}_{3}\right)$ if the concentration exceeds $0.05 \mathrm{mg} / \mathrm{L}$. In our present study, the concentration of dissolved ammonia was found to vary from $0.16-0.57 \mathrm{mg} / \mathrm{L}$, which was high enough to pose adverse effects on aquatic life.

\section{Determination of metal concentrations}

The distribution of heavy metal concentrations during the two seasons in the surface water from the Meghna River estuary is presented in Table 1. Cumulatively, the result revealed that the average dissolved metal concentration in both seasons was the following the order of $\mathrm{Cr}>\mathrm{As}>\mathrm{Cd}>\mathrm{Pb}$, respectively. Moreover, the concentration range for $\mathrm{Cr}, \mathrm{As}, \mathrm{Cd}$, and $\mathrm{Pb}$ was as follows: 0.036-0.054 (mean $0.045 \pm 0.005$ ), 0.012-0.036 (mean $0.024 \pm 0.007$ ), $0.009-0.050$ (mean $0.018 \pm 0.012$ ), and 0.007-0.014 (mean
$0.009 \pm 0.007)$ considering for all seasons, respectively. Being a non-essential element, $\mathrm{Pb}$ can cause many adverse health complications, like neurotoxicity and nephrotoxicity (García-Lestón et al. 2010). Almost in all sampling sites on the Meghna River estuary, except S8 and S9, the concentration of $\mathrm{Pb}$ was attributed to be higher extent in the winter season in comparison with the values found in the summer season. However, the variation of the $\mathrm{Pb}$ concentration in both seasons had no significant difference $(p>0.05)$. The paired student $t$-test showed that there was no statistically significant difference for $\mathrm{Pb}$ concentration $\left(t_{\text {stat }}=2.24<t_{\text {critic }}=2.26, p=0.052\right)$ between two seasons in Meghna River estuary at a 95\% confidence level. Comparatively, the mean concentration of $\mathrm{Pb}$ ranges from 0.0051 to $0.0185 \mathrm{mg} / \mathrm{L}$ (Tables 1 and 2). This study that the average $\mathrm{Pb}$ concentration for this study was lower than the recommended value $(0.01 \mathrm{mg} / \mathrm{L})$ set by WHO (1993). Reversely, the average $\mathrm{Pb}$ concentration was higher than the criterion continuous concentration value $(0.0025 \mathrm{mg} / \mathrm{L})$ set by USEPA (2009) and world average background concentrations $(0.0002 \mathrm{mg} / \mathrm{L})$ value (Klavinš et al. 2000), which are presented in Table 2.

Cadmium (Cd) is believed to be an element that is able in producing chronic toxicity, even presenting at a concentration of near $1 \mathrm{mg} / \mathrm{kg}$ (Ahmed et al. 2021). Moreover, Cd is considered potentially more lethal in comparison with other available metals in aquatic body (Rahman et al. 2012). The maximum mean concentration of $\mathrm{Cd}$ in the Meghna River estuary was observed in the winter season. It was assumed that the immobilized deposits flushing down the river might have been caused for such concentrations of $\mathrm{Cd}$ in the investigated area (Rahman et al. 2019a, b). Waste streams discharged from various industrial processes, such as metallurgical alloys, porcelains, metal electroplating, photographic materials, dye works, and textile silk-screening industries, were responsible for the presence of high extent of Cd in wastewaters (Rahman and Islam 2009). The concentrations of $\mathrm{Cd}$ in the Meghna River estuary were observed as $0.0057-0.0152$ and $0.0116-0.0921 \mathrm{mg} / \mathrm{L}$ in the summer and winter seasons, respectively. The paired student $t$-test showed that there was no statistically significant difference for Cd concentration $\left(t_{\text {stat }}=2.01<t_{\text {critic }}=2.26, p=0.076\right.$ ) between two seasons in Meghna River estuary at a 95\% confidence level. However, the highest concentration of $\mathrm{Cd}$ was observed in S10, which was four times higher compared to other samples. As per the WHO guideline, the maximum permissible concentration of $\mathrm{Cd}$ in drinking water is $0.003 \mathrm{mg} / \mathrm{L}$ (WHO 1993). In almost all of the analyzed samples, the concentration of $\mathrm{Cd}$ in the Meghna River estuary was found well above the maximum recommended values set by WHO (1993), USEPA (2009) and world average background concentrations value (Klavinš et al. 2000) (Table 2). 
Table 2 A comparison on the concentration of metals studied with that of other study groups

\begin{tabular}{|c|c|c|c|c|c|}
\hline Estuary, Location & As (mg/L) & $\mathrm{Cr}(\mathrm{mg} / \mathrm{L})$ & $\mathrm{Cd}(\mathrm{mg} / \mathrm{L})$ & $\mathrm{Pb}(\mathrm{mg} / \mathrm{L})$ & References \\
\hline Meghna River Estuary & 0.024 & 0.045 & 0.018 & 0.009 & This study \\
\hline Yellow River Estuary, China & $0.16-5.89(2.59)$ & NA & $0.10-1.90(0.66)$ & $0.42-13.3(5.61)$ & Wang et al. (2018) \\
\hline Yellow River Estuary, China & $0.43-1.40(0.92)$ & NA & $1.10-3.22(0.68)$ & $0.22-1.33(0.51)$ & Tang et al. (2010) \\
\hline Yangtze River Estuary, China & NA & NA & $0.08-0.09(0.08)$ & $2.28-2.43(2.36)$ & An et al. (2010) \\
\hline Pearl River Estuary, China & $0.16-8.18(2.55)$ & NA & $0.0015-0.30(0.12)$ & $0.19-4.58(1.61)$ & Zhang et al. (2013) \\
\hline Yalujiang Estuary, China & $3.8-11.3(6.36)$ & $0.113-0.14$ & $0.05-0.41(0.20)$ & $12.3-29.9(17.95)$ & Li et al. (2017) \\
\hline Kaohsiung Harbor area, China & $0.8-10$ & ND & ND & ND-0.6 & Lin et al. (2013) \\
\hline Port Jackson, Australia & NA & NG & NA & $0.006-0.104$ & Hatje et al. (2003) \\
\hline \multicolumn{6}{|l|}{ Guideline limit } \\
\hline CCC (Criterion continuous concentration) & 0.15 & 0.011 & 0.00025 & 0.0025 & USEPA (2009) \\
\hline CMC (Criteria maximum concentration) & 0.34 & 0.016 & 0.002 & 0.065 & \\
\hline WHO (World Health Organization) & 0.01 & 0.05 & 0.003 & 0.01 & WHO (1993) \\
\hline Bangladesh drinking water standards & 0.05 & 0.05 & 0.0005 & 0.05 & ECR (1997) \\
\hline Background concentrations, world average & NG & NG & 0.00002 & 0.0002 & Klavinš et al. (2000) \\
\hline
\end{tabular}

$\mathrm{Cr}$ is one of the strong oxidizing agents with a corrosive and oxidizing appearance that to be more poisonous and widely used in corrosion control, tanning, plating, pigment production (Hossain et al. 2021). The water samples from the Meghna River estuary showed the maximum concentration of chromium $(\mathrm{Cr})$ in the winter season $(0.058 \mathrm{mg} / \mathrm{L})$ and the minimum concentration was detected in summer (0.054 mg/L). A significant difference for $\mathrm{Cr}$ concentration in the Meghna River estuary between winter and summer season was observed by the paired student $t$-test $\left(t_{\text {stat }}=2.52<t_{\text {critic }}=2.26, p=0.032\right)$ at a $95 \%$ confidence level. However, the highest $\mathrm{Cr}$ concentration was observed in S4, and the lowest one was in S5. The WHO recommended maximum concentration of $\mathrm{Cr}$ in drinking water is $0.05 \mathrm{mg} / \mathrm{L}$ (WHO 1993). It was apparent that the water samples had a $\mathrm{Cr}$ concentration well above the WHO recommended value (Table 2).

Being pervasive, arsenic (As) is potentially toxic, and a trace amount can cause chronic toxicity to animals. Both anthropogenic and natural processes contributed to make a widespread distribution of As in an aquatic environment. Therefore, concentration of As followed a similar trend observed for other metal contents: The winter season showed a higher concentration than that of the summer season but distribution was not significantly different $(p>0.05)$. The winter season displayed As concentration of 0.01159 to $0.0385 \mathrm{mg} / \mathrm{L}$. The sample $\mathrm{S} 4$ demonstrated the highest concentration of As, while the sample S10 showed the lowest value. The allowable maximum concentration of As for potable water is $0.05 \mathrm{mg} / \mathrm{L}$, suggested by Bangladesh Center for Advanced Studies (BCAS), (BCAS 1998), whereas the WHO endorsement is $0.01 \mathrm{mg} / \mathrm{L}$ (USEPA 1996; WHO 1993). It is mentionable that the mean concentration of As in the present study area exceeded the WHO guideline provision and the USEPA guideline, although the value was below the BCAS threshold limit.

The concentrations of dissolved heavy metals have been compared with other notable estuaries along with their respective recommended standards (Table 2 ). We could see clearly that the concentration range of $\mathrm{Cr}$ in the Meghna River Estuary is higher than that of the value found in the Yalujiang Estuary (Li et al. 2017), a bit lower compared to other locations (Table 2). The concentration ranges of As, $\mathrm{Cd}$, and $\mathrm{Pb}$ in the present study do not follow a definite trend to be compared with other estuaries.

\section{Sources of contamination}

The adopted Kolmogorov-Smirnov and Shapiro-Wilk tests revealed that the distribution of metals over the entire zones of study followed a non-normal distribution curve. The Levene's test indicated that the variables were in line with a non-homogeneity dispersion $(p \leq 0.05)$ pattern. Along with these distribution scenarios, the Kruskal-Wallis test revealed our investigation as a non-normal and non-homogeneity distribution of elements. Overall, the metal concentrations were significantly different along the study sites concerning both winter and summer seasons $(p \leq 0.05)$. The correlations among the measured water quality parameters with that of the concentrations of metals were authenticated and are represented in Table 3. Correlation between physicochemical parameters and metal concentrations was represented to identify the influential factor to the metal elements (Wei et al. 2018). The correlations have been categorized into two groups: positive and negative (Ahmed et al. 2019a; Saha et al. 2016a, b). The concentration of As was found to correlate positively and significantly with salinity $(r=0.246)$, but negatively correlated with temperature $(r=-0.800)$. 
Table 3 The Spearman order rank correlation coefficient among the physicochemical parameters of heavy metals and surface water in the Meghna River Estuary, Noakhali, Bangladesh

\begin{tabular}{|c|c|c|c|c|c|c|c|c|c|c|}
\hline & Temp & $\mathrm{pH}$ & DO & Hardness & Ammonia & Salinity & As & $\mathrm{Cr}$ & $\mathrm{Cd}$ & $\mathrm{Pb}$ \\
\hline Temp & 1 & & & & & & & & & \\
\hline $\mathrm{pH}$ & $-0.253^{*}$ & 1 & & & & & & & & \\
\hline Do & $0.286^{*}$ & 0.071 & 1 & & & & & & & \\
\hline Hardness & -0.155 & $0.396^{* *}$ & $0.644 * *$ & 1 & & & & & & \\
\hline Ammonia & $0.209^{*}$ & 0.255 & $-0.252 *$ & -0.049 & 1 & & & & & \\
\hline Salinity & $-0.269^{*}$ & -0.166 & $-0.287^{*}$ & $-0.406^{* *}$ & -0.133 & 1 & & & & \\
\hline As & $-0.800 * *$ & -0.085 & -0.35 & -0.098 & -0.155 & $0.246^{*}$ & 1 & & & \\
\hline $\mathrm{Cr}$ & $-0.203^{*}$ & $0.543^{* *}$ & $0.227 *$ & $0.431 * *$ & $-0.329 * *$ & 0.025 & 0.143 & 1 & & \\
\hline $\mathrm{Cd}$ & $-0.207^{*}$ & $-0.297 *$ & 0.177 & $0.257^{*}$ & $-0.475^{* *}$ & $-0.466^{* *}$ & $0.263^{*}$ & -0.077 & 1 & \\
\hline $\mathrm{Pb}$ & $-0.226^{*}$ & $0.277 *$ & 0.006 & -0.21 & 0.154 & -0.091 & $0.301 * *$ & 0.045 & -0.351 & 1 \\
\hline
\end{tabular}

*Correlation is significant at the 0.05 level (2-tailed)

**Correlation is significant at the 0.01 level (2-tailed)

The concentration of $\mathrm{Cr}$ is positively correlated with $\mathrm{pH}$ $(r=0.543)$, DO $(r=0.277)$, and hardness $(r=0.431)$, whereas it was negatively correlated with temperature $(r=-0.203)$ and ammonia $(r=-0.329)$. The Cd content in surface water was negatively correlated with temperature $(r=-0.207), \mathrm{pH}(r=-0.297)$, ammonia $(r=-0.475)$, and salinity $(r=-0.466)$, but positively correlated with hardness $(r=0.227)$. The concentration of $\mathrm{Pb}$ was also positively correlated with $\mathrm{pH}(r=0.277)$, whereas a negative correlation was observed with temperature $(r=-0.226)$. In fact, the temperature was negatively correlated with all the tested metals. The $\mathrm{pH}$ was significantly and positively correlated with $\mathrm{Cr}$ and $\mathrm{Pb}$, but demonstrated a negative correlation with Cd. Again, the DO also showed a positive correlation with Cr. Likewise, the hardness was positively correlated with both $\mathrm{Cr}$ and $\mathrm{Cd}$, while the ammonia was negatively correlated to the concentration of the metals. The water salinity was positively correlated with As, but inversely correlated to $\mathrm{Cd}$. We observed that temperature had negligible impact for all metal attribution to the water body. However, $\mathrm{pH}, \mathrm{DO}$, and hardness showed a considerable influential effect to $\mathrm{Cr}$ than that of $\mathrm{Cd}$ and $\mathrm{Pb}$.

The principal component analysis (PCA) was conducted to determine the correlation and retrospective sources of the tested elements (Ahmed et al. 2019a, b). The corresponded PCA was executed following rotated component plot concerning the loadings depicted in Fig. 2. The PCA plot was based on the eigenvalues which was greater than 1, and the relations were apparent. In Fig. 2, all the metal contents moved toward the positive direction of the axis AX 1 , which revealed that they were associated each other (Wei et al. 2018). The executed PCA resulted in two corresponding factor, PC 1 and PC 2 with the cumulative variance of $70.24 \%$. PC 1 contributed for $47.17 \%$, while PC 2 rendered $23.07 \%$ of total variance. PC 1 was dominated by As due to

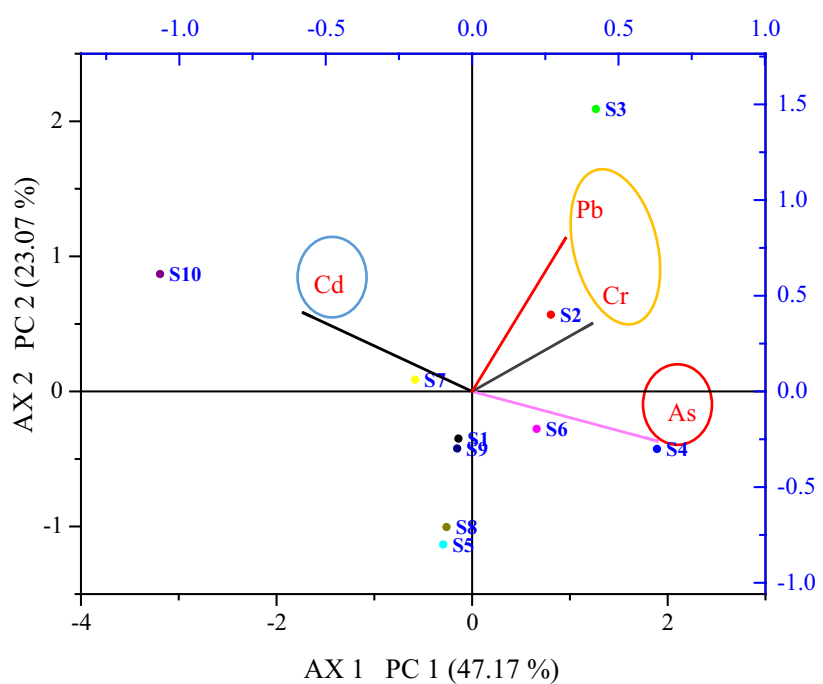

Fig. 2 Principal component analysis (PCA) of the selective metals along the study area (Noakhali District, Bangladesh)

the high loading of $46.44 \%$, whereas $\mathrm{Pb}$ controlled over PC 2 with the high loading of $51.12 \%$. Also, the components were plotted associated with the sites which response values were related to the components. We observed that the corresponded value of the metal components in the PCA plot was greater than 0.000 except $\mathrm{Cd}$. Meanwhile, $\mathrm{As}$ and $\mathrm{Pb}$ were exhibited the significant variance; therefore, axis $1 \mathrm{might}$ be considered to be influenced by anthropogenic activities. Components $\mathrm{Pb}$ and $\mathrm{Cr}$ confined in the first quadrant, $\mathrm{Cd}$ was in second quadrant, and As ran in fourth quadrant. Therefore, the anthropogenic activities were influencing the water quality deterioration regarding the metal contents along with the natural origins (Wei et al. 2018). Generally, As, $\mathrm{Cr}$, and $\mathrm{Cd}$ are being used in fertilizers, electroplating, nickel-cadmium batteries, cadmium remaining alloys, 
foils, oils, etc. (Mathivanan and Rajaram 2014). As has also long-term usage as an element in fungicides and algaecides (Burgos-Núñez et al. 2017), widely applicable to agricultural practices. In battery industries, for instance, chemical plants use $\mathrm{Cd}$ to manufacture and discharge wastages that contain a high level of Cd contents (An et al. 2010). On the other hand, historically, $\mathrm{Pb}$ is well known as an anti-corrosive element, and used in painting purposes in steels and mills, as well as an anti-knocking agent in gasoline and diesel fuels (Abdollahi et al. 2013). Apart from oil leakage from boat and steamers, motor exhausts contribute a large amount of $\mathrm{Pb}$ in the water body (Mathivanan and Rajaram 2014). It has been suggested that the industrial activities heavily contributed to PC 2.

The cluster analysis is mostly used for the presentation of similar group of items at the sampling site against the observed parameters with respect to special variability (Hossain et al. 2018; Li et al. 2009). A similar group of

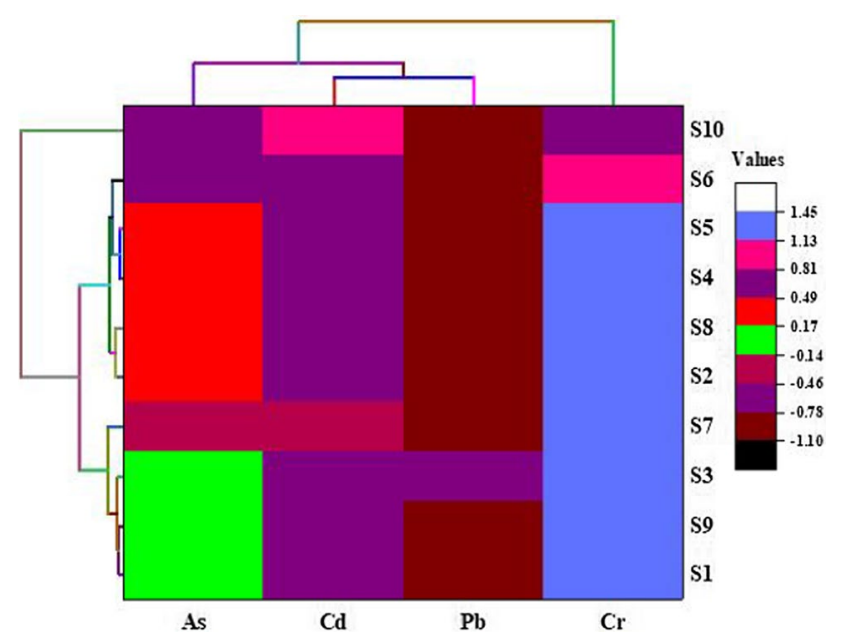

Fig. 3 Two-way hierarchical cluster heat map of the metal concentration along with the sampling sites site is presented in a cluster group, and the dissimilar site is plotted in another cluster group to identify the specific areas to portray the extent of contamination (Sundaray et al. 2011). In the present study, the two-way hierarchical cluster heatmap as well as dendrogram, developed by the Ward linkage method with Euclidean distance, was prepared, and the result is depicted in Fig. 3. In the vertical portion, the dendrogram provided two clusters: $\mathrm{As}, \mathrm{Cd}$, and $\mathrm{Cr}$ had been confined in cluster 1 , and $\mathrm{Pb}$ was displayed in cluster 2, which mostly conformed in line with the PCA result. Such findings strongly confirmed a similar origin of the selected metal elements. In contrast, the horizontal dendrogram rendered three clusters, where S1, S9, S3, and S7 imparted to cluster 1; cluster 2 imported S2, S8, S5, and S6 sites, and finally, S10 was confined to cluster 3 .

\section{Estimation of the pollution load in the study area}

The pollution status can be identified by the assessment of the seasonal PI to express the current status of contamination in the study area. The results are represented in Table 4 where the cumulative PI values were ranged from 2.61 (in S3) to 4.24 (in S8) with a mean of 3.33 in the summer season, and 3.63 (in S10) to 5.52 (in S4) with a mean of 4.45 in the winter season. Among the investigated metals, $\mathrm{Cd}$ expressed a relatively higher level of contamination (3.58) at S9 in the winter season. In the result, on an average measurement, $50 \%$ of all sites were moderately affected, and the remaining $50 \%$ were highly affected by the metals that surpassed the respective contamination line.

\section{Health risk assessment}

\section{Estimation of daily intake (EDI)}

To determine the adverse effect on human health through the two distinct routes (ingestion and dermal contact), metal
Table 4 The seasonal and the cumulative pollution load in the study area

\begin{tabular}{|c|c|c|c|c|c|c|c|c|c|c|}
\hline \multirow[t]{2}{*}{ Sites } & \multicolumn{2}{|l|}{ As (PIi) } & \multicolumn{2}{|l|}{$\mathrm{Cr}$ (PIi) } & \multicolumn{2}{|l|}{ Cd (PIi) } & \multicolumn{2}{|l|}{$\mathrm{Pb}$ (PIi) } & \multicolumn{2}{|c|}{ PI (cumulative) } \\
\hline & Summer & Winter & Summer & Winter & Summer & Winter & Summer & Winter & Summer & winter \\
\hline S1 & 0.27 & 0.54 & 0.76 & 1.1 & 2.56 & 2.46 & 0.1 & 0.19 & 3.69 & 4.29 \\
\hline $\mathrm{S} 2$ & 0.65 & 0.43 & 0.65 & 1.15 & 2.38 & 2.94 & 0.17 & 0.26 & 3.85 & 4.78 \\
\hline S3 & 0.32 & 0.69 & 0.97 & 0.96 & 1.14 & 2.31 & 0.18 & 0.37 & 2.61 & 4.34 \\
\hline S4 & 0.73 & 0.72 & 1.07 & 1.1 & 1.62 & 3.54 & 0.13 & 0.15 & 3.55 & 5.5 \\
\hline S5 & 0.44 & 0.56 & 0.86 & 0.59 & 1.32 & 2.32 & 0.13 & 0.19 & 2.76 & 3.67 \\
\hline S6 & 0.55 & 0.77 & 0.64 & 1.05 & 2.26 & 2.8 & 0.14 & 0.23 & 3.59 & 4.84 \\
\hline S7 & 0.27 & 0.43 & 0.82 & 1.03 & 1.54 & 2.14 & 0.17 & 0.15 & 2.8 & 3.74 \\
\hline S8 & 0.38 & 0.63 & 0.67 & 0.99 & 3.04 & 2.76 & 0.15 & 0.12 & 4.25 & 4.51 \\
\hline S9 & 0.28 & 0.62 & 0.92 & 0.85 & 1.98 & 3.58 & 0.16 & 0.15 & 3.33 & 5.2 \\
\hline S10 & 0.24 & 0.23 & 0.82 & 0.84 & 1.69 & 2.42 & 0.14 & 0.14 & 2.9 & 3.64 \\
\hline Mean & 0.41 & 0.56 & 0.82 & 0.97 & 1.95 & 2.73 & 0.15 & 0.19 & 3.33 & 4.45 \\
\hline
\end{tabular}


concentration in the surface water was concerned (Mitra et al. 2018). The EDI value for the selective pathways for different age groups is presented in Table 5. The table reflected that the adults exhibited the relatively higher EDI values through ingestion and dermal routes, which had been organized in the descending order: $\mathrm{Cr}\left(1.91 \times 10^{-5}\right)>\mathrm{As}$ $\left(1.05 \times 10^{-5}\right)>\mathrm{Cd}\left(5.01 \times 10^{-6}\right)>\mathrm{Pb}\left(3.66 \times 10^{-6}\right)$ (for ingestion) and $\mathrm{As}\left(1.43 \times 10^{-6}\right)>\mathrm{Cd}\left(8.72 \times 10^{-11}\right)>\mathrm{Pb}$ $\left(1.67 \times 10^{-8}\right)>\mathrm{Cr}\left(18.72 \times 10^{-11}\right)$ (for dermal contact). On the other hand, the trend of EDI for children was as follows: $\mathrm{Cr}\left(1.91 \times 10^{-5}\right)>\mathrm{Pb}\left(1.71 \times 10^{-5}\right)>\mathrm{As}\left(4.19 \times 10^{-6}\right)>\mathrm{Cd}$ $\left(2.01 \times 10^{-6}\right)$ (for ingestion) and $\mathrm{As}\left(2.81 \times 10^{-7}\right)>\mathrm{Cd}$ $\left(4.49 \times 10^{-9}\right)>\mathrm{Pb}\left(3.28 \times 10^{-9}\right)>\mathrm{Cr}\left(2.00 \times 10^{-10}\right)$. The results revealed that $\mathrm{Cr}$ expressed the highest value for both adult and children through the ingestion route, but for the dermal route, As showed the maximum values for all consumers. In terms of metal intake, the ingestion route plays the vital role in the EDI, which was comparable to the results observed by Alves et al. (2014), Saha et al. (2017), and Mitra et al. (2018).

\section{Non-carcinogenic risk assessment}

Hazard quotient (HQ) The HQ for the measured four elements from the river stream through two exposure pathways is presented in Table 5. Results revealed that the HQ from both ingestion and dermal pathways was $<1$ for all group aged people. The findings also indicated that the consumption of metals from the surface water exhibited the acceptable HQ limits; hence, people would not experience adverse health effect. The mean of HQ values for adults has been organized as follows: As $\left(3.49 \times 10^{-2}\right)>\mathrm{Cr}$ $\left(6.38 \times 10^{-3}\right)>\mathrm{Cd} \quad\left(5.01 \times 10^{-3}\right)>\mathrm{Pb} \quad\left(3.66 \times 10^{-3}\right) \quad$ (for ingestion), and $\mathrm{As}\left(1.19 \times 10^{-1}\right)>\mathrm{Cd}\left(2.29 \times 10^{-4}\right)>\mathrm{Pb}$ $\left(3.97 \times 10^{-5}\right)>\mathrm{Cr}\left(1.33 \times 10^{-5}\right)$ (for dermal route). For the children group, the hierarchical of $\mathrm{HQ}$ values were found as: $\mathrm{Pb}\left(1.71 \times 10^{-2}\right)>\mathrm{As}\left(1.40 \times 10^{-2}\right)>\mathrm{Cr}\left(6.38 \times 10^{-3}\right)>\mathrm{Cd}$ $\left(2.01 \times 10^{-3}\right)$ (Table 5). Nevertheless, the children from S4 site were exposed to the maximum HQ $\left(3.47 \times 10^{-2}\right)$ due to the intake of As through the dermal contact.

Hazard index $(\mathrm{HI})$ The non-carcinogenic risk due to intake of $\mathrm{As}, \mathrm{Cr}, \mathrm{Cd}$, and $\mathrm{Pb}$ through ingestion and dermal routes was assessed for the two age groups and represented in Fig. 4a, b. The calculated HI for adult ranged from $8.87 \times 10^{-2}$ to $2.45 \times 10^{-1}$ with the mean of $1.70 \times 10^{-1}$. The highest HI value $(0.245)$ was observed in $\mathrm{S} 6$, and the lowest one was found in S10. Meanwhile, the children exhibited the highest HI value (0.079), which was exposed to $S 4$, whereas the lowest value $(0.040)$ was observed in S10. The results implied that the adults were more sufferer than the children. Moreover, on an average, the $\mathrm{HI}$ of adults was 2.70-fold higher than the children. However, the cumulative HI val- ues through all exposure pathways were in the acceptable threshold limit $(\mathrm{HI}<1)$ for all concerned age groups. The results demonstrate that the consumers would not suffer the non-carcinogenic health effect due to drink of the surface water from the study area.

Carcinogenic risk Carcinogenic risk (CR) of $\mathrm{As}, \mathrm{Cr}, \mathrm{Cd}$, and $\mathrm{Pb}$ was evaluated for all consumers and potential pathways, presented in Table 5 and shown in Fig. 4c, d. The range of $\mathrm{CR}$ for $\mathrm{As}, \mathrm{Cd}$, and $\mathrm{Pb}$ was $1.05 \times 10^{-6}-3.17 \times 10^{-6}$, $2.53 \times 10^{-7}-3.92 \times 10^{-5}$, and $1.13 \times 10^{-10}-5.03 \times 10^{-8}$, respectively, for adults and children; the $\mathrm{CR}$ of metals range $2.05 \times 10^{-7}-9.28 \times 10^{-6}, 4.97 \times 10^{-8}-1.57 \times 10^{-5}$ and $2.22 \times 10^{-11}-2.35 \times 10^{-7}$. The result indicated that the ingestion route was also the dominant pathway of metal exposure to human body than that of the dermal contact. A similar observation was found by Mitra et al. (2018). The total lifetime exposure of $\mathrm{CR}$ for the adult and the children through different pathways remained within the acceptable guideline range $\left(10^{-6}-10^{-4}\right)$ (Fig. 4c, d). Hence, the children and the adult, fortunately, would not pose any serious carcinogenic health risk due to a bulk consumption of surface water from the Meghna River estuary. However, the adults were found 2.54 times susceptible to carcinogenic risk than the children. Actually, mostly $90 \%$ of risk concern was estimated due to the intake of water containing As (USEPA 1993). In addition, the inorganic form of As is termed as the potential carcinogenic agent compared to the organic form (Zhong et al. 2018), and at least $10 \%$ of total As can be evaluated as in inorganic state (Baki et al. 2018).

\section{Conclusion}

The highest concentration level was observed for $\mathrm{Cr}$, followed by $\mathrm{As}, \mathrm{Cd}$, and $\mathrm{Pb}$. The distribution of metal elements was significantly different. The present study suggested that the source of metal contamination in the Meghna River estuary was the anthropogenic and natural origins. Also, the physicochemical features, like temperature, $\mathrm{pH}, \mathrm{DO}$, hardness, ammonia, and salinity of the water samples represented significant variance along the study area. The attribution of metal contamination to adult and children was concerned for ingestion and dermal pathways. People taken up more $\mathrm{Cr}$ than any other metal through the ingestion route; on the contrary, As was taken through dermal pathway at a high extent. The results showed that the adults were exposed to more non-carcinogenic impact than the children. However, values of HQ and HI of the considered local community were found less than unity $(<1)$. Therefore, people living near the study area would not experience the non-carcinogenic health risk. Based on the suggested guideline range of $10^{-6}$ to $10^{-4}$, the cancer

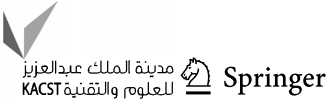




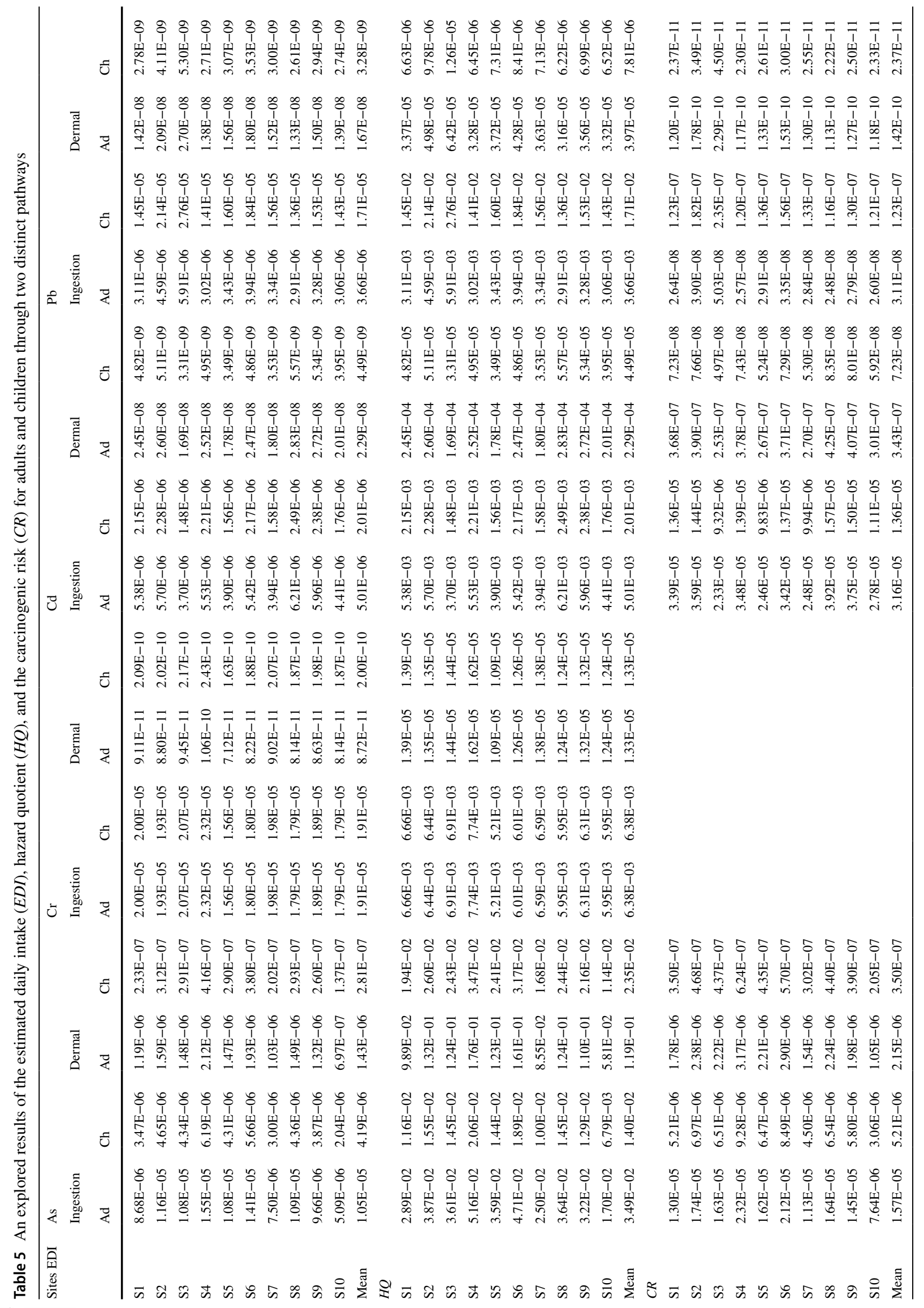




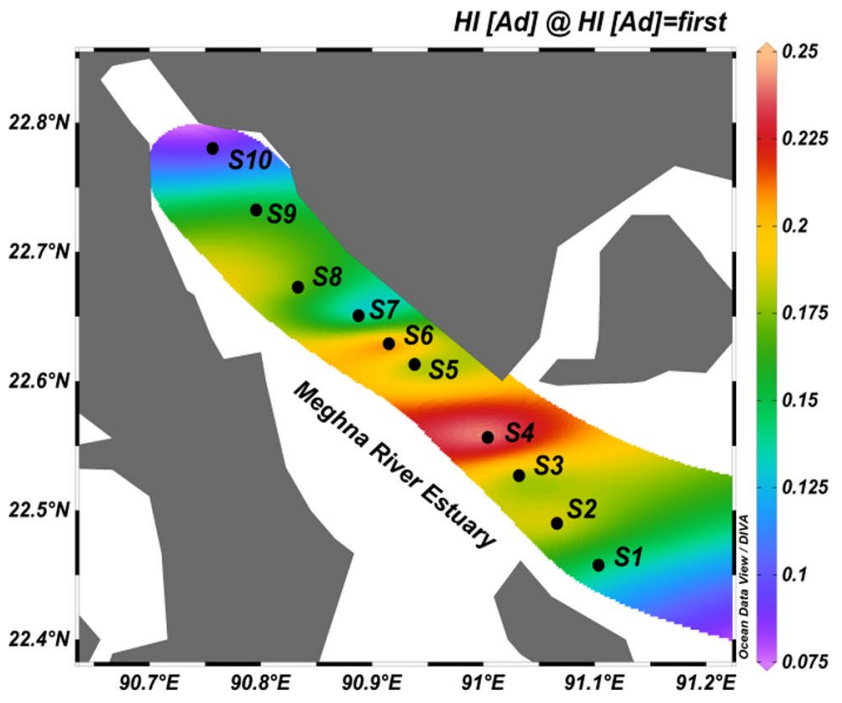

(a) Adults

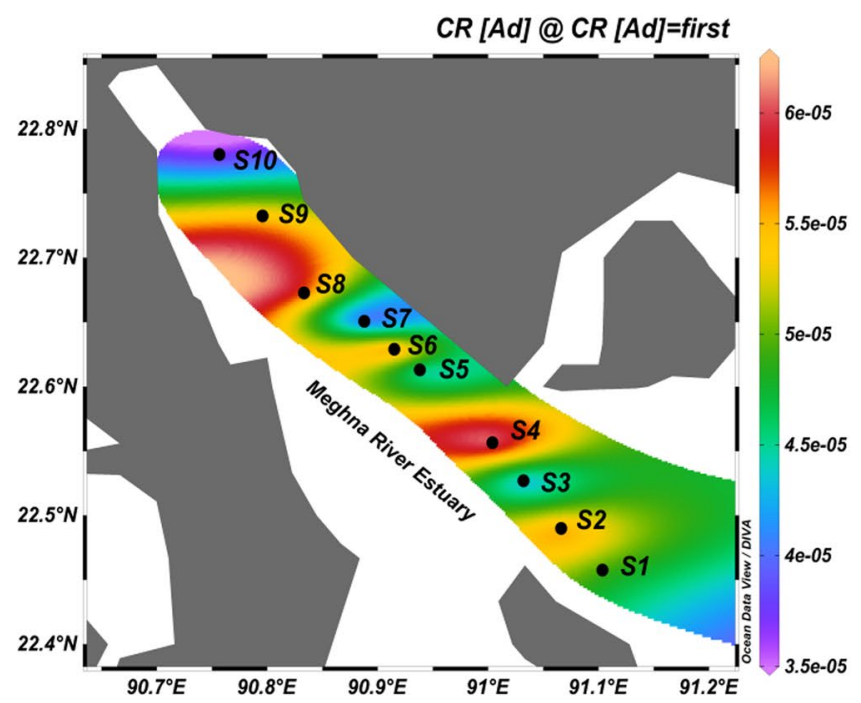

(c) Adults

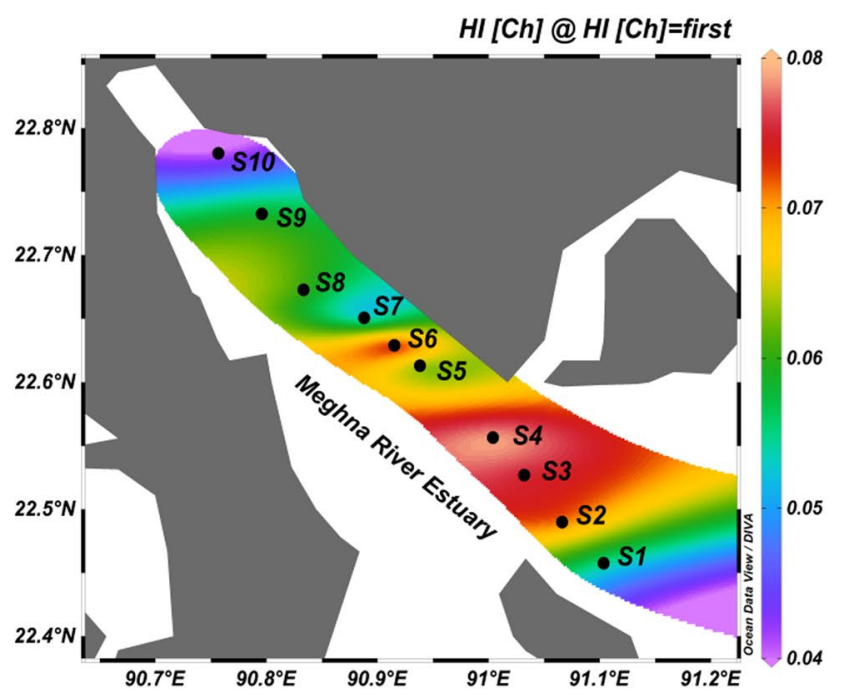

(b) Children

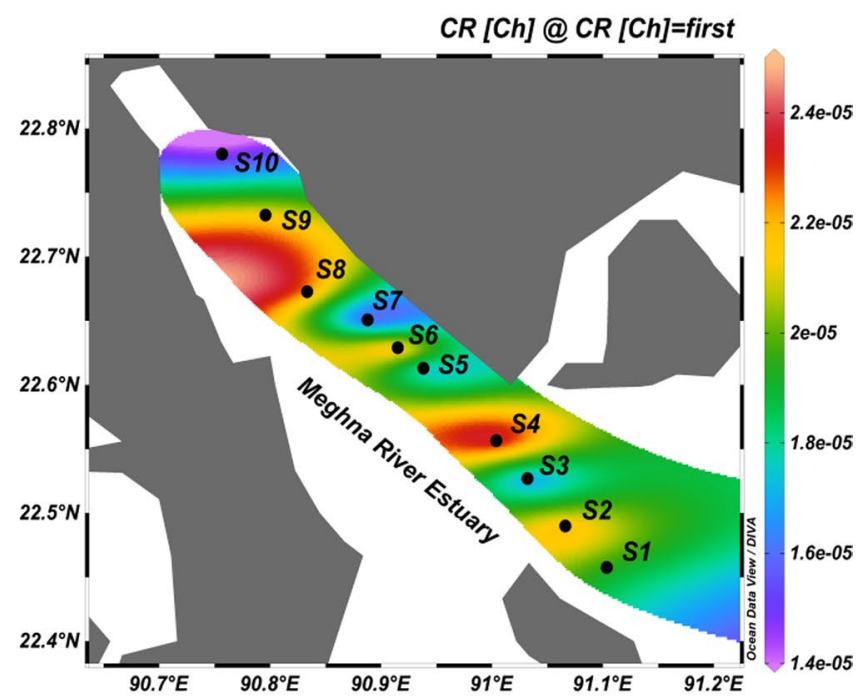

(d) Children

Fig. 4 Hazard index of adults and children along with the river estuary $(\mathbf{a}, \mathbf{b})$ and carcinogenic risk of nearby dwellers of the selected sites (c, d)

risk (CR) levels from the study area were in the acceptable limit for lifetime exposure to the metal contents. However, the authors would like to recommendation to adopt proper inspection regarding the water quality deterioration through heavy metal intrusion to the Meghna River estuary due to the increasing states of the metal attribution from various anthropogenic activities.

Acknowledgements The authors thank the authority of Forensic Science Laboratory of Rapid Action Battalions Headquarters, Bangladesh, for providing laboratory facilities to analyze sediment samples using the conventional analytical techniques.

Funding The author(s) received no specific funding for this work.

\section{Declarations}

Conflict of interest The authors declare that they have no conflict of interest.

Open Access This article is licensed under a Creative Commons Attribution 4.0 International License, which permits use, sharing, adaptation, distribution and reproduction in any medium or format, as long as you give appropriate credit to the original author(s) and the source, provide a link to the Creative Commons licence, and indicate if changes were made. The images or other third party material in this article are included in the article's Creative Commons licence, unless indicated otherwise in a credit line to the material. If material is not included in the article's Creative Commons licence and your intended use is not permitted by statutory regulation or exceeds the permitted use, you will

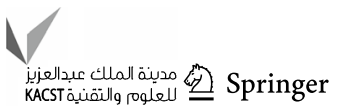


need to obtain permission directly from the copyright holder. To view a copy of this licence, visit http://creativecommons.org/licenses/by/4.0/.

\section{References}

Abdollahi S, Raoufi Z, Faghiri I, Savari A, Nikpour Y, Mansouri A (2013) Contamination levels and spatial distributions of heavy metals and PAHs in surface sediment of Imam Khomeini Port, Persian Gulf. Iran Mar Pollut Bull 71(1-2):336-345

Adamu CI, Nganje TN, Edet A (2015) Heavy metal contamination and health risk assessment associated with abandoned barite mines in Cross River State, southeastern Nigeria. Environ Nanotechnol Monit Manag 3:10-21

Ahmed AS, Hossain MB, Babu SOF, Rahman MM, Sarker MSI (2021) Human health risk assessment of heavy metals in water from the subtropical river, Gomti, Bangladesh. Environ Nanotechnol, Monit Manag 15:100416

Ahmed AS, Rahman M, Sultana S, Babu SOF, Sarker MSI (2019a) Bioaccumulation and heavy metal concentration in tissues of some commercial fishes from the Meghna River Estuary in Bangladesh and human health implications. Mar Pollut Bull 145:436-447

Ahmed AS, Sultana S, Habib A, Ullah H, Musa N, Hossain MB, Sarker MSI (2019b) Bioaccumulation of heavy metals in some commercially important fishes from a tropical river estuary suggests higher potential health risk in children than adults. PLoS ONE 14(10):e0219336

Ahmed MK, Shaheen N, Islam MS, Habibullah-Al-Mamun M, Islam S, Banu CP (2015a) Trace elements in two staple cereals (rice and wheat) and associated health risk implications in Bangladesh. Environ Monit Assess 187(6):326

Ahmed MK, Baki MA, Islam MS, Kundu GK, Habibullah-Al-Mamun M, Sarkar SK, Hossain MM (2015b) Human health risk assessment of heavy metals in tropical fish and shellfish collected from the river Buriganga. Bangladesh Environ Sci Pollut Res 22(20):15880-15890

Alves RI, Sampaio CF, Nadal M, Schuhmacher M, Domingo JL, Segura-Muñoz SI (2014) Metal concentrations in surface water and sediments from Pardo River, Brazil: human health risks. Environ Res 133:149-155

Alzieu C (2000) Impact of tributyltin on marine invertebrates. Ecotoxicology 9(1):71-76

An Q, Wu Y, Wang J, Li Z (2010) Assessment of dissolved heavy metal in the Yangtze River estuary and its adjacent sea. China Environ Monit Assess 164(1-4):173-187

Azam MH (2000) Sensitivity of the tidal signal around Meghna Estuary to the changes in river discharge: a model study. In: Proc. 12th congress of the Asia and Pacific division of the international association for hydraulic engineering and research, Bangkok, Thailand

Baki MA, Hossain MM, Akter J, Quraishi SB, Shojib MFH, Ullah AA, Khan MF (2018) Concentration of heavy metals in seafood (fishes, shrimp, lobster and crabs) and human health assessment in Saint Martin island, Bangladesh. Ecotoxicol Environ Saf 159:153-163

Banglapedia (2015a) Meghna River. http://en.banglapedia.org/index. php/Meghna_River. Accessed date: 28 May 2021

Banglapedia, (2015b) Surma-Meghna River System. http://en.bangl apedia.org/index.php/Surma-Meghna_River_System. Accessed 30 May 2021

Barnett T, Malone R, Pennell W, Stammer D, Semtner B, Washington W (2004) The effects of climate change on water resources in the west: introduction and overview. Clim Change 62(1):1-11

BCAS (1998) Guide to the environmental conservation Act 1995 and rules 1997. Ministry of Environment and Forest, Bangladesh
Bhattacharya BD, Nayak DC, Sarkar SK, Biswas SN, Rakshit D, Ahmed MK (2015) Distribution of dissolved trace metals in coastal regions of Indian Sundarban mangrove wetland: a multivariate approach. J Clean Prod 96:233-243

Bhuyan MS, Bakar MA, Akhtar A, Hossain MB, Ali MM, Islam MS (2017) Heavy metal contamination in surface water and sediment of the Meghna River, Bangladesh. Environ Nanotechnol, Monit Manag 8:273-279

Burgos-Núñez S, Navarro-Frómeta A, Marrugo-Negrete J, Enamorado-Montes G, Urango-Cárdenas I (2017) Polycyclic aromatic hydrocarbons and heavy metals in the Cispata Bay, Colombia: a marine tropical ecosystem. Mar Pollut Bull 120(1-2):379-386

Cancer IAFRO (2011) Agents classified by the IARC Monographs. IARC Monographs on the Christensen F, Olson EC (1957) Cadmium Poisoning. Report of a Fatal Case, with Discussion of Pathology and Clinical Aspects. Arch Indust Health 16(1):8-13

de Souza MAA, Spencer K, Kloas W, Toffolon M, Zarfl C (2016) Metal fate and effects in estuaries: a review and conceptual model for better understanding of toxicity. Sci Total Environ 541:268-281

DoE (1997) Environment conservation rules, E.C.R- schedule 3, standards for water. Department of Environment of Bangladesh. https://www.elaw.org/system/files/Bangladesh+--+Environmen tal+Conservation+Rules, +1997.pdf

ECR (1997) The Environment Conservation Rules, Government of the People's Republic of Bangladesh. https://www.elaw.org/system/files/Bangladesh+--+Environmental+Conservation+Rules ,+1997.pdf. Accessed 21 June 2021

Epa US (1989) Risk assessment guidance for superfund. Human, Washington

EQS (1991) Environmental quality standards for Bangladesh. Department of Environment, Government of the People's Republic of Bangladesh. $43 \mathrm{p}$

García-Lestón J, Méndez J, Pásaro E, Laffon B (2010) Genotoxic effects of lead: an updated review. Environ Int 36(6):623-636

Guo S, Qian L, Shi H, Barry T, Cao Q, Liu J (2010) Effects of tributyltin (TBT) on Xenopus tropicalis embryos at environmentally relevant concentrations. Chemosphere 79:529-533

Hassan M, Rahman MAT, Saha B, Kamal AKI (2015) Status of heavy metals in water and sediment of the Meghna River. Bangladesh Am J Environ Sci 11(6):427

Hatje V, Apte SC, Hales LT, Birch GF (2003) Dissolved trace metal distributions in port Jackson estuary (Sydney harbour). Aust Mar Pollut Bull 46(6):719-730

Hossain MB, Ahmed ASS, Sarker MSI (2018) Human health risks of $\mathrm{Hg}$, As, $\mathrm{Mn}$, and $\mathrm{Cr}$ through consumption of fish, Ticto barb (Puntius ticto) from a tropical river. Bangladesh Environ Sci Pollut Res 25(31):31727-31736

Hossain MB, Semme SA, Ahmed ASS, Hossain MK, Porag GS, Parvin A, Sekar S (2021) Contamination levels and ecological risk of heavy metals in sediments from the tidal river Halda. Bangladesh Arab J Geosci 14(3):1-12

Hossain MB, Shanta TB, Ahmed ASS, Hossain MK, Semme SA (2019) Baseline study of heavy metal contamination in the Sangu River estuary, Chattogram, Bangladesh. Mar Pollut Bull 140:255-261

Hu B, Jia X, Hu J, Xu D, Xia F, Li Y (2017) Assessment of heavy metal pollution and health risks in the soil-plant-human system in the Yangtze River delta, China. Int J Adv Technol Eng Sci 14:1042

Islam ARMT, Islam HT, Mia MU, Khan R, Habib MA, BodrudDoza M, Chu R (2020) Co-distribution, possible origins, status and potential health risk of trace elements in surface water sources from six major river basins, Bangladesh. Chemosphere 249:126180

Islam MS, Ahmed MK, Habibullah-Al-Mamun M, Hoque MF (2015a) Preliminary assessment of heavy metal contamination 
in surface sediments from a river in Bangladesh. Environ Earth Sci 73(4): 1837-1848

Islam MS, Ahmed MK, Raknuzzaman M, Habibullah-Al-Mamun M, Islam MK (2015b) Heavy metal pollution in surface water and sediment: a preliminary assessment of an urban river in a developing country. Ecol Indic 48:282-291

Jakobsen F, Azam MH, Mahboob-Ul-Kabir M (2002) Residual flow in the Meghna Estuary on the coastline of Bangladesh. Estuar Coast Shelf Sci 55(4):587-597

Kamunda C, Mathuthu M, Madhuku M (2016) Health risk assessment of heavy metals in soils from Witwatersrand gold mining basin, South Africa. Int J Environ Res Public Health 13(7):663

Klavinš M, Briede A, Rodinov V, Kokorite I, Parele E, Klavina I (2000) Heavy metals in rivers of Latvia. Sci Total Environ 262(1-2):175-183

Li H, Lin L, Ye S, Li H, Fan J (2017) Assessment of nutrient and heavy metal contamination in the seawater and sediment of Yalujiang Estuary. Mar Pollut Bull 117(1-2):499-506

Li J, He M, Han W, Gu Y (2009) Analysis and assessment on heavy metal sources in the coastal soils developed from alluvial deposits using multivariate statistical methods. J Hazard Mater 164(2-3):976-981

Lin YC, Chang-Chien GP, Chiang PC, Chen WH, Lin YC (2013) Multivariate analysis of heavy metal contaminations in seawater and sediments from a heavily industrialized harbor in Southern Taiwan. Mar Pollut Bull 76(1-2):266-275

Liu M, Xie H, He Y, Zhang Q, Sun X, Yu C, Wang X (2019) Sources and transport of methylmercury in the Yangtze River and the impact of the Three Gorges Dam. Water Res 166:115042

Liu S, Lou S, Kuang C, Huang W, Chen W, Zhang J, Zhong G (2011) Water quality assessment by pollution-index method in the coastal waters of Hebei Province in western Bohai Sea. China Mar Pollut Bull 62(10):2220-2229

Liu X, Song Q, Tang Y, Li W, Xu J, Wu J, Brookes PC (2013) Human health risk assessment of heavy metals in soil-vegetable system: a multi-medium analysis. Sci Total Environ 463:530-540

Mathivanan K, Rajaram RD (2014) Anthropogenic influences on toxic metals in water and sediment samples collected from industrially polluted Cuddalore coast, Southeast coast of India. Environ Earth Sci 72(4):997-1010

MEA (2005) Millennium ecosystem assessment, ecosystem and human wellbeing; synthesis. Island Press, Washington, p 112

Mitra S, Sarkar SK, Raja P, Biswas JK, Murugan K (2018) Dissolved trace elements in Hooghly (Ganges) River Estuary, India: risk assessment and implications for management. Mar Pollut Bull 133:402-414

O'Connor MI, Bruno JF, Gaines SD, Halpern BS, Lester SE, Kinlan BP, Weiss JM (2007) Temperature control of larval dispersal and the implications for marine ecology, evolution, and conservation. Proc Natl Acad Sci 104(4):1266-1271

Rahman MS, Hossain MB, Babu SOF, Rahman M, Ahmed AS, Jolly YN, Akter S (2019a) Source of metal contamination in sediment, their ecological risk, and phytoremediation ability of the studied mangrove plants in ship breaking area, Bangladesh. Mar Pollut Bull 141:137-146

Rahman MS, Islam MR (2009) Adsorption of Cd (II) ions from synthetic waste water using maple sawdust. Energy Sour A 32(3):222-231

Rahman MS, Khan MDH, Jolly YN, Kabir J, Akter S, Salam A (2019b) Assessing risk to human health for heavy metal contamination through street dust in the Southeast Asian Megacity: Dhaka, Bangladesh. Sci Total Environ 660:1610-1622

Rahman MS, Molla AH, Saha N, Rahman A (2012) Study on heavy metals levels and its risk assessment in some edible fishes from Bangshi River, Savar, Dhaka. Bangladesh Food Chem 134(4):1847-1854
Saha N, Mollah MZI, Alam MF, Rahman MS (2016a) Seasonal investigation of heavy metals in marine fishes captured from the Bay of Bengal and the implications for human health risk assessment. Food Cont 70:110-118

Saha N, Rahman MS, Ahmed MB, Zhou JL, Ngo HH, Guo W (2017) Industrial metal pollution in water and probabilistic assessment of human health risk. J Environ Manage 185:70-78

Saha N, Rahman MS, Jolly YN, Rahman A, Sattar MA, Hai MA (2016b) Spatial distribution and contamination assessment of six heavy metals in soils and their transfer into mature tobacco plants in Kushtia District. Bangladesh Environ Sci Pollut Res 23(4):3414-3426

Saleem M, Iqbal J, Shah MH (2015) Geochemical speciation, anthropogenic contamination, risk assessment and source identification of selected metals in freshwater sediments-a case study from Mangla Lake, Pakistan. Environ Nanotechnol Monit Manage 4:27-36

Singh UK, Kumar B (2017) Pathways of heavy metals contamination and associated human health risk in Ajay River basin, India. Chemosphere 174:183-199

Sun Z, Mou X, Tong C, Wang C, Xie Z, Song H, Lv Y (2015) Spatial variations and bioaccumulation of heavy metals in intertidal zone of the Yellow River estuary, China. CATENA 126:43-52

Sundaray SK, Nayak BB, Lin S, Bhatta D (2011) Geochemical speciation and risk assessment of heavy metals in the river estuarine sediments - a case study: Mahanadi basin, India. J Hazard Mater 186(2-3): 1837-1846

Tang A, Liu R, Ling M, Xu L, Wang J (2010) Distribution characteristics and controlling factors of soluble heavy metals in the Yellow River Estuary and Adjacent Sea. Procedia Environ Sci 2:1193-1198

Tchounwou PB, Yedjou CG, Patlolla AK, Sutton DJ (2012) Heavy metal toxicity and the environment. Mol Clin Environ Toxicol 101:133-164

US EPA (1991) United States Environmental Protection Agency, Human Health Evaluation Manual, Supplemental Guideline, Standard Default Exposure Factors, OSWER Dir. 9285, p 603

USEPA (1993) Guideline document for arsenic in shellfish. U.S. Food and Drug Administration, Washington, pp 25-27

USEPA (1996) Drinking water regulations and health advisories. US Environmental Protection Agency, Washington

USEPA (2000) Risk-based concentration table. United States Environmental Protection Agency, Washington

USEPA (2002) (United States Environmental Protection Agency). Supplemental Guidance for Developing Soil Screening Levels for Superfund Sites OSWER 9355.4-24. United States Environmental Protection Agency, Washington

USEPA (2011a) USEPA regional screening level (RSL) Summary Table: November 2011

USEPA (2011b) Exposure Factors Handbook 2011 edition (Final)

USEPA (2014) Risk assessment guidance for superfund volume 1. Human Health Evaluation

USEPA (2009) National Recommended water quality criteria, office of water. Office of Science and Technology (4304T), Washington

USEPA (2010) Integrated risk information system (iris). United States Environmental Protection Agency. https://www.epa.gov/irris/ index.html. Accessed Jan 2019

USEPA (2010) Risk-Based concentration Table. http://www.epa.gov/ reg3hwmd/risk/human/index.htm

Wang X, Zhao L, Xu H, Zhang X (2018) Spatial and seasonal characteristics of dissolved heavy metals in the surface seawater of the Yellow River Estuary, China. Mar Pollut Bull 137:465-473

Wei H, Yu H, Zhang G, Pan H, Lv C, Meng F (2018) Revealing the correlations between heavy metals and water quality, with insight into the potential factors and variations through canonical correlation analysis in an upstream tributary. Ecol Ind 90:485-493

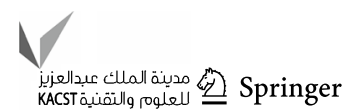


Wei W, Liu X, Sun P, Wang X, Zhu H, Hong M, Zhao J (2014) Simple whole-cell biodetection and bioremediation of heavy metals based on an engineered lead-specific operon. Environ Sci Technol 48(6):3363-3371

WHO (1993) Guidelines for drinking-water quality, 2nd edn. World Health Organization, Geneva

Winder M, Schindler DE (2004) Climate change uncouples trophic interactions in an aquatic ecosystem. Ecology 85(8):2100-2106

Yin S, Feng C, Li Y, Yin L, Shen Z (2015) Heavy metal pollution in the surface water of the Yangtze Estuary: a 5-year follow-up study. Chemosphere 138:718-725

Yuan GL, Sun TH, Han P, Li J, Lang XX (2014) Source identification and ecological risk assessment of heavy metals in topsoil using environmental geochemical mapping: typical urban renewal area in Beijing, China. J Geochem Explor 136:40-47

Zhai X, Xia J, Zhang Y (2014) Water quality variation in the highly disturbed Huai River Basin, China from 1994 to 2005 by multistatistical analyses. Sci Tot Environ 496:594-606

Zhang D, Zhang X, Tian L, Ye F, Huang X, Zeng Y, Fan M (2013) Seasonal and spatial dynamics of trace elements in water and sediment from Pearl River Estuary. South China Environ Earth Sci 68(4):1053-1063
Zhao XM, Yao LA, Ma QL, Zhou GJ, Wang L, Fang QL, Xu ZC (2018) Distribution and ecological risk assessment of cadmium in water and sediment in Longjiang River, China: implication on water quality management after pollution accident. Chemosphere 194:107-116

Zheng NA, Wang Q, Liang Z, Zheng D (2008) Characterization of heavy metal concentrations in the sediments of three freshwater rivers in Huludao City. Northeast China Environ Poll 154(1):135-142

Zhong W, Zhang Y, Wu Z, Yang R, Chen X, Yang J, Zhu L (2018) Health risk assessment of heavy metals in freshwater fish in the central and eastern North China. Ecotoxicol Environ Saf 157:343-349

Publisher's Note Springer Nature remains neutral with regard to jurisdictional claims in published maps and institutional affiliations. 